Vol. 19(2010): 327-340.

\title{
Nitrogen losses from grass ley after slurry application - surface broadcasting vs. injection
}

Jaana Uusi-Kämppä and Pasi K. Mattila

MTT Agrifood Research Finland, Plant Production Research, FI-31600 Jokioinen, Finland, e-mail: jaana.uusi-kamppa@mtt.fi

\begin{abstract}
As the livestock numbers on Finnish dairy farms have increased and most fields on dairy farms are under grass, it has become common to spread cattle slurry over grasslands. To estimate environmental effects of recurrent slurry applications, a 5-year field study was performed to compare nitrogen $(\mathrm{N})$ losses to water and ammonia losses to air by volatilization, when cattle slurry was either surface broadcast or injected into clay soil after grass cuttings. Slurry was spread on the grass in summer (1996-1997) or both in summer and autumn (1998-2000). Biomass N uptake before grass harvesting and amount of soil mineral $\mathrm{N}$ in spring and autumn were measured and field $\mathrm{N}$ balances were calculated. Despite cool weather, up to one third of the ammonium $\mathrm{N}$ of broadcast slurries was lost through ammonia volatilization after application in autumn, but injection effectively prevented losses. The mean surface runoff losses of total $\mathrm{N}$ were negligible (0.3-4.6 $\mathrm{kg} \mathrm{ha}^{-1} \mathrm{yr}^{-1}$ ) with the highest loss of $13 \mathrm{~kg} \mathrm{ha}^{-1} \mathrm{yr}^{-1}$ measured after slurry broadcasting to wet soil in autumn and followed with heavy rains. A substantial part (24-55\%) of the applied mineral $\mathrm{N}$ was not recovered by the foregoing measurements.
\end{abstract}

Key-words: Slurry application, grassland, surface runoff, nitrogen, nitrogen uptake, $\mathrm{NH}_{3}$ volatilization, nitrogen balance, surface broadcasting, injection

\section{Introduction}

While many small dairy farms have shut down milk production, the livestock density and number of livestock farms have increased in certain regions in western and central Finland during recent dec- ades. At present, most dairy farms prefer almost continuous grass cultivation to crop rotation with cereals and grasses. Consequently, slurry is spread onto fields of silage grass instead of using earlier methods where slurry was applied to cereal fields before autumn ploughing or before spring tillage. Due to the soil wetness and risk of soil compac- 
Uusi-Kämppä, J. et al. Nitrogen losses from broadcast or injected slurry

tion in spring, however, only mineral fertilizer is often surface applied to grass in the beginning of the growing season whereas cattle slurry is applied after the first cut. If the growing season is extremely rainy, it may not be possible to spread slurry with heavy machinery on wet soils in summer. Then the slurry tanks are emptied in the autumn to provide storage capacity for the winter months.

In Finland, slurry is applied to grassland surface either by conventional broadcasting or by more recently adopted band spreading and trailing shoe techniques, whereas injection is used to apply slurry below the soil surface. Surface application is an easy and cheap process but it leaves the manure prone to $\mathrm{NH}_{3}$ volatilization (Braschkat et al. 1997, Mattila and Joki-Tokola 2003) and surface runoff (Turtola and Kemppainen 1998). Injection of slurry might be better environmentally but it is more expensive and more difficult than broadcast application. Top-dress fertilization of grass fields with mineral fertilizers is also a typical complementary method.

The purpose of this study was to compare two different slurry application methods - surface broadcasting and injection - on grass fields. The former method is a cheap and commonly used practice on most dairy farms whereas the latter is considered as a difficult method to use, particularly on stony soils. In this study, we investigated whether slurry injection could be recommended in given environmental conditions in boreal climates. Losses of total nitrogen (TN), ammonium $\mathrm{N}\left(\mathrm{NH}_{4}^{+}-\mathrm{N}\right.$, hereafter $\left.\mathrm{NH}_{4}-\mathrm{N}\right)$ and nitrate $\mathrm{N}\left(\mathrm{NO}_{3}^{-}-\mathrm{N}\right.$, hereafter $\left.\mathrm{NO}_{3}-\mathrm{N}\right)$ to surface runoff water from the surfaceapplied slurry were compared to losses from injected slurry or mineral fertilization on a grass field. Knowledge of ammonia $\left(\mathrm{NH}_{3}\right)$ losses to air due to the methods in cool autumn weather was also lacking. Nitrogen uptake by grass was measured for $\mathrm{N}$ balances. The amounts of soil mineral N (SMN; $\mathrm{NH}_{4}-\mathrm{N}$ plus $\mathrm{NO}_{3}-\mathrm{N}$ ) at different depths were also measured and $\mathrm{N}$ balances were calculated to allow an estimation of the risk for $\mathrm{NO}_{3}$ leaching.

\section{Material and methods}

\section{The experimental field}

The study was performed on an eight-plot experimental field (0.34 ha; Uusi-Kämppä and Heinonen-Tanski 2008) located in Jokioinen, south west Finland $\left(60^{\circ} 49^{\prime} \mathrm{N} 23^{\circ} 30^{\prime} \mathrm{E}\right)$. The area had a long-term (1971-2000) mean annual precipitation of $607 \mathrm{~mm}$ and mean annual temperature of $4.3^{\circ} \mathrm{C}$, with the mean temperatures of the coldest (February) and the warmest (July) months being -6.5 and $16.1{ }^{\circ} \mathrm{C}$, respectively (Drebs et al. 2002). The soil was classified as Typic Cryaquept (Soil Survey Staff 1996) containing $61 \%$ clay in the plough layer. The concentrations of $\mathrm{Ca}, \mathrm{K}, \mathrm{Mg}$ and $\mathrm{P}$ in the plough layer were at a satisfactory or good level.

The experimental plots with slopes of $0.9-1.7 \%$ were isolated from each other by plastic film to a depth of $0.6 \mathrm{~m}$ and by soil banks. Uncultivated 10 -m wide buffer zones were established at the lower edge of the plots since buffers (mostly 3-m or 15-m wide) are typical on Finnish fields. Tenmetre wide buffer area in the upper edges of the plots of total length of $70 \mathrm{~m}$, and 0.5-m (19982000) or 1.5-m (1996-1997) wide borders on both sides of the plots were also untreated, with neither soil nor plant sampling, nor slurry application, due to difficulties to drive and work with tractors and spreaders on those areas on the narrow plots. The grass ley on the experimental field consisted for the most part of timothy (Phleum pratense) and meadow fescue (Festuca pratensis) sown in June 1995. The grass ley was cut twice a year, with the first cut always in June and the second cut in late August (1996), September $(1997,1998)$ or early October (2000).

\section{Treatments and applications}

The experimental treatments were as follows:

1. Surface broadcasting (SB) of cattle slurry onto the grass ley (three replicates); 
Vol. 19(2010): 327-340.

2. Injection (IN) of cattle slurry into the grass ley (depth of 0.05-0.1 m; three replicates); and

3. Mineral fertilization (MF) - top-dress fertilization onto the grass ley (two replicates).

Slurry was applied annually to grass ley after the first cut in 1996-1997 (Phase I) and biannually after the first and the second cuts in 1998-2000 (Phase II). In Phase I, the application rates of mineral $\mathrm{N}$ (160 kg ha ${ }^{-1} \mathrm{yr}^{-1}$ including $\mathrm{NH}_{4}-\mathrm{N}$ of slurry and $\mathrm{NH}_{4}-\mathrm{N}$ and $\mathrm{NO}_{3}-\mathrm{N}$ of mineral fertilizer) and total $\mathrm{P}\left(36 \mathrm{~kg} \mathrm{ha}^{-1} \mathrm{yr}^{-1}\right)$ represented the nutrient amounts allowed by Finnish 'good agricultural practice' and the average used on most Finnish farms. In Phase II, the corresponding amounts were 230 and $66 \mathrm{~kg} \mathrm{ha}^{-1} \mathrm{yr}^{-1}$ for mineral $\mathrm{N}$ and total $\mathrm{P}$, respectively. In autumn, slurry amounts of 33-42 t $\mathrm{ha}^{-1}$ were applied, although the maximum allowed autumn slurry amount at that time was $30 \mathrm{t} \mathrm{ha}^{-1}$
(Finlex 1998). In fact, $120-160 \mathrm{~kg} \mathrm{ha}^{-1}$ more TN in slurry was applied than allowed in the nitrate directive (170 $\left.\mathrm{kg} \mathrm{TN} \mathrm{ha}^{-1} \mathrm{yr}^{-1}\right)$ to detect possible environmental risks due to over-dosing of manure. More details about $\mathrm{P}$ applications in slurry and fertilizers, slurry properties, and storage tanks have been presented by Uusi-Kämppä and HeinonenTanski (2008).

In Phase I (annual slurry application in June, 1996-1997), cattle slurry (34-61 t ha-1, Table 1) was applied to an area of $3 \mathrm{~m} \times 50 \mathrm{~m}$ by a "Vogelsang" spreader on slurry plots after the first grass cut in June. Slurry was either applied to the soil surface with a band spreading unit equipped with a small splash plate under each hose, or injected with an injector that had 10 tines with $0.3 \mathrm{~m}$ spacing, each equipped with a disc coulter and a press wheel (Kapuinen 1998).

Table 1. Application dates, amended plot area, amount of slurry, and total nitrogen (TN) applications in slurry (s) and mineral fertilizer (mf) in plots where slurry was surface broadcast (SB) or injected (IN) into soil and in mineral fertilized (MF) plots. Values in parenthesis indicate the application rate of mineral $\mathrm{N}$ in slurry and mineral fertilizer.

\begin{tabular}{|c|c|c|c|c|c|}
\hline \multirow[t]{2}{*}{$\overline{\text { Dates }}$} & \multirow{2}{*}{$\begin{array}{c}\text { Area, } \\
\mathrm{m}^{2}\end{array}$} & \multirow{2}{*}{$\begin{array}{l}\text { Slurry rate, } \mathrm{t} \mathrm{ha}^{-1} \\
\text { (wet weight) }\end{array}$} & \multicolumn{3}{|c|}{$\mathrm{TN}\left(\right.$ mineral N) kg ha ${ }^{-1}$} \\
\hline & & & SB & IN & MF \\
\hline \multicolumn{6}{|c|}{ Annual slurry application (Study phase I) } \\
\hline 14 May 1996 & 350 & & $112(112) \mathrm{mf}$ & $112(112) \mathrm{mf}$ & $112(112) \mathrm{mf}$ \\
\hline 17-19 June 1996 & 150 & $34-37$ & $134(78) \mathrm{s}$ & $146(85) \mathrm{s}$ & $81(81) \mathrm{mf}$ \\
\hline 12 May 1997 & 350 & & $49(49) \mathrm{mf}$ & $49(49) \mathrm{mf}$ & $49(49) \mathrm{mf}$ \\
\hline 26-27 June 1997 & 150 & 61 & $148(78) \mathrm{s}$ & $148(78) \mathrm{s}$ & $80(80) \mathrm{mf}$ \\
\hline Total 1996-1997 & & & $443(317)$ & $455(324)$ & $322(322) \mathrm{mf}$ \\
\hline Mean 1996-1997 & & 48 & $222(159)$ & $228(162)$ & $161(161) \mathrm{mf}$ \\
\hline \multicolumn{6}{|c|}{ Biannual slurry application (Study phase II) } \\
\hline 11 May 1998 & 350 & & $48(48) \mathrm{mf}$ & $48(48) \mathrm{mf}$ & $48(48) \mathrm{mf}$ \\
\hline 29 June 1998 & 250 & $50-52$ & $187(94) \mathrm{s}$ & $194(97) \mathrm{s}$ & $92(92) \mathrm{mf}$ \\
\hline 16 October 1998 & 250 & $38-42$ & $140(73) \mathrm{s}$ & $155(80) \mathrm{s}$ & \\
\hline 11 May 1999 & 250 & & $61(61) \mathrm{mf}$ & $61(61) \mathrm{mf}$ & $100(100) \mathrm{mf}$ \\
\hline 30 June 1999 & 250 & $59-62$ & $209(112) \mathrm{s}$ & $219(118) \mathrm{s}$ & $100(100) \mathrm{mf}$ \\
\hline 27 October 1999 & 250 & $33-38$ & $105(58) \mathrm{s}$ & $120(67) \mathrm{s}$ & \\
\hline 8 May 2000 & 250 & & 69 (69) mf & 69 (69) mf & $100(100) \mathrm{mf}$ \\
\hline 21-22 June 2000 & 250 & $47-52$ & $170(94) \mathrm{s}$ & $188(105) \mathrm{s}$ & $100(100) \mathrm{mf}$ \\
\hline 23 October 2000 & 250 & $33-36$ & $119(59) \mathrm{s}$ & $130(64) \mathrm{s}$ & \\
\hline Total 1998-2000 & & & $1108(668)$ & 1184 (709) & $540(540) \mathrm{mf}$ \\
\hline Mean 1998-2000 & & 90 & $369(223)$ & $395(236)$ & $180(180) \mathrm{mf}$ \\
\hline
\end{tabular}


Uusi-Kämppä, J. et al. Nitrogen losses from broadcast or injected slurry

During Phase II (biannual slurry application in June and October, 1998-2000) slurry was applied by a "Teho-Lotina" spreader that had an injector with $0.47 \mathrm{~m}$ tine spacing and disc coulters but no press wheels. Broadcast spreading was carried out by holding the injector up while each tine was equipped with a small splash plate. The slurry amounts were slightly higher in the IN than $\mathrm{SB}$ plots due to a lower driving speed during injection. In autumn 2000, the field was ploughed three days after the slurry application, when the ammonia volatilization measurements had been finished.

Mineral fertilizer was spread by a "Juko" fertilizer drill to all plots in spring and to MF plots after the first cut in June. In spring 1996, NK fertilizer (20\% N and 15\% K; Table 1) was surface applied to all plots. Since then ammonium nitrate fertilizer $(26 \% \mathrm{~N})$ was spread in spring, except in spring 1999 and spring 2000 when NPK fertilizer (20\% N, 4\% $\mathrm{P}$ and $7 \% \mathrm{~K}$ ) was spread on the MF plots only. Due to half of the $\mathrm{NH}_{4}-\mathrm{N}$ in slurry spread in autumn was assumed to be available for plants in the following spring (Ministry of Agriculture and Forestry 1998), 39 and $31 \mathrm{~kg} \mathrm{ha}^{-1}$ less fertilizer $\mathrm{N}$ was applied to slurry plots than to MF plots in spring 1999 and in spring 2000, respectively. On the MF plots, NPK fertilizer $(20 \% \mathrm{~N}, 4 \% \mathrm{P}$ and $7 \% \mathrm{~K})$ was surface applied every summer, except in the first summer, when NPK fertilizer $(18 \% \mathrm{~N}, 5 \% \mathrm{P}, 10 \% \mathrm{~K})$ was spread.

\section{Measurement of ammonia volatilization}

Volatilization of $\mathrm{NH}_{3}$ was measured after the autumn applications of slurry (SB and IN) in 1999 and 2000 by the equilibrium concentration technique, also called the "JTI method" (Svensson 1994). The method uses passive diffusional $\mathrm{NH}_{3}$ samplers that are placed on treated areas both in ambient air and under ventilated chambers. The ammonia volatilization rate in ambient air is calculated from the amounts of $\mathrm{NH}_{3}$ absorbed by the samplers. Air temperature is used to calculate the diffusion coefficient of $\mathrm{NH}_{3}$. The concentration of $\mathrm{NH}_{3}$ inside the chambers was used as a measure of $\mathrm{NH}_{3}$ volatilization potential without the effect of varying wind conditions in ambient air.

Ammonia volatilization was measured in the daytime starting at 5-15 $\mathrm{min}$ after the application of slurry and lasting for 2.75-4 h divided into two consecutive periods. On the following two days, $\mathrm{NH}_{3}$ measurement began about $24 \mathrm{~h}$ and about $48 \mathrm{~h}$ after the slurry application and lasted for $3.5-5 \mathrm{~h}$ on each of the days. The measurement was carried out in the three replicate plots of both SB and IN. Two chambers and two ambient air sampler holders were placed on each plot. Air temperature was measured with a thermohygrograph at about $0.2 \mathrm{~m}$ height and wind speed was measured with a cup anemometer at $2 \mathrm{~m}$ height. The volatilization of $\mathrm{NH}_{3}$ between measurement periods was interpolated by calculating the average emission values before and after an interval and correcting it based on the temperature and wind speed that prevailed during the interval. The procedure is described in detail by Malgeryd (1996).

\section{Water sampling and analyses}

Surface and near-surface runoff (referred to hereafter as surface runoff) to a depth of $0.3 \mathrm{~m}$ was collected in a modified collector trench planned by Puustinen (1994) at the lower end of each plot and fed by pipes into 8 plastic tanks $\left(2.0 \mathrm{~m}^{3}\right)$ buried in the soil. Water volume was measured by flow meters (Oy TeknoMonta Ab, JOT-company, 1992) and representative subsamples were taken through samplers (Fig. 1) for laboratory analyses when the tanks were emptied. Water was sampled 16-27 times per year, with most samplings in spring and autumn. The time interval between water samplings in peak runoff periods varied from a day to two weeks, depending on rains and snowmelts.

The volume of runoff water was calculated from the whole plot area, whereas the $\mathrm{N}$ losses were calculated from the slurry applied source area. On the border areas, the mean $\mathrm{TN}$ losses through surface runoff were estimated to be negligible (ca $0.5 \mathrm{~kg} \mathrm{ha}^{-1}$ $\mathrm{yr}^{-1}$ ) according to the $\mathrm{TN}$ concentrations of surface runoff water measured earlier on nearby plots under 
Vol. 19(2010): 327-340.

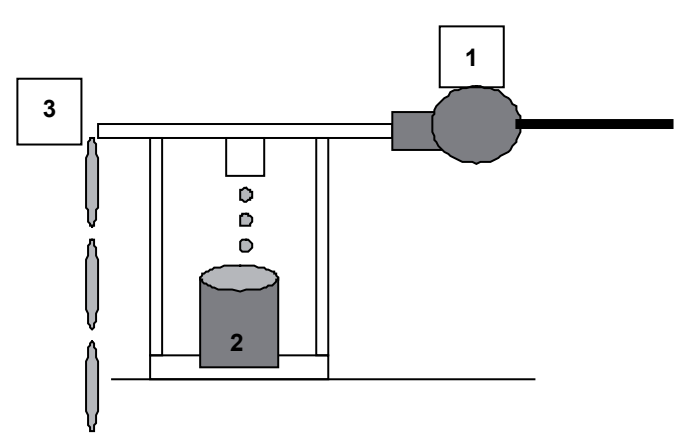

Fig. 1. Sampling of surface runoff: 1, water from the collector tank flows through the flow meter; 2 , the water sample drips into a pail; 3 , the rest of the water flows through an outlet.

unfertilized grass (Turtola and Paajanen 1995). In spring 1997, the surface runoff results from one SB plot and one MF plot were omitted, due to freezing of the outlet pipes. Precipitation was measured at Jokioinen Observatory, Finnish Meterological Institute, situated $0.5 \mathrm{~km}$ from the field.

Water samples were stored in polyethylene bottles for periods from a few days to a few weeks in the dark $\left(4^{\circ} \mathrm{C}\right)$ before determining the nutrient concentrations. The storage time probably did not have a large impact on the concentrations of TN and $\mathrm{NO}_{3}-\mathrm{N}$, but the concentrations of $\mathrm{NH}_{4}-\mathrm{N}$ may have decreased during the prolonged storage (Turtola 1989). For the determinations of $\mathrm{NH}_{4}-\mathrm{N}$ and $\mathrm{NO}_{3}-\mathrm{N}$, the samples were filtered through a membrane filter $(0.2 \mu \mathrm{m})$ and analysed with a Skalar autoanalyser according to Finnish standard methods (SFS 3030, SFS 3032). The concentration of TN was determined from unfiltered water samples by oxidation of $\mathrm{N}$ compounds to $\mathrm{NO}_{3}$ in alkaline solution (SFS 3031).

\section{Soil sampling and analyses}

Because the drainage water was not measured, both the amounts of $\mathrm{NH}_{4}-\mathrm{N}$ and $\mathrm{NO}_{3}-\mathrm{N}$ as well as their sum $(\mathrm{SMN})$ in the $0-60 \mathrm{~cm}$ soil layers were used to indicate the risk of $\mathrm{N}$ leaching from the grass ley. Soil samples were taken separately from each plot in spring and autumn before the application of mineral fertilizer or slurry (Uusi-Kämppä and HeinonenTanski 2008). The samples taken in spring 1997 were omitted because the field had been fertilized a few days earlier.

Soil samples were frozen immediately after the sampling. For $\mathrm{NH}_{4}-\mathrm{N}$ and $\mathrm{NO}_{3}-\mathrm{N}$ analyses, soils were thawed overnight $\left(4^{\circ} \mathrm{C}\right)$, and $40 \mathrm{ml}$ of moist soil was subsequently extracted with $100 \mathrm{ml}$ of 2 $\mathrm{M} \mathrm{KCl}$ for 16 hours (Sippola and Yläranta 1985). After filtration, concentrations of $\mathrm{NH}_{4}-\mathrm{N}$ and $\mathrm{NO}_{3}$ $\mathrm{N}$ were measured with a Skalar autoanalyser. The concentrations of TN and carbon (C) were determined using the C-N-autoanalyser (LecoCN-2000, Leco Corporation, St.Joseph, MI, USA).

\section{Other samplings and calculations of nitro- gen balances}

Slurry samples were taken during spreading and analysed for concentrations of TN (Kjeldahl) and $\mathrm{NH}_{4}-\mathrm{N}$ as described by Mattila and Joki-Tokola (2003).

Above-ground biomass was sampled before harvesting the grass. Samples $\left(0.64 \mathrm{~m}^{2}\right)$ were collected from each plot so that the grass was cut leaving a stubble of $1 \mathrm{~cm}$. Plant samples were dried at $60^{\circ} \mathrm{C}$ overnight for TN analysis with a LECO analyser and at $105^{\circ} \mathrm{C}$ for dry matter (DM) determination.

Field $\mathrm{N}$ balance was estimated as the difference between $\mathrm{N}$ inputs and outputs (Equation 1). The $\mathrm{N}$ uptake of grass, ammonia volatilization and $\mathrm{TN}$ in surface runoff were considered as outputs in the calculations. Ammonia volatilization from summer-applied slurry was estimated to be $40 \%$ of the applied $\mathrm{NH}_{4}-\mathrm{N}$ for surface application and $0.4 \%$ for injection, based on the results of Mattila and Joki-Tokola (2003). Volatilization from autumnapplied slurry was taken from the results of the $\mathrm{NH}_{3}$ measurements carried out in this study. Ammonia volatilization from mineral fertilizer, in turn, was estimated to be $1.6 \%$ of the applied N (Grönroos et al. 2009).

Equation 1:

$\mathrm{N}$ balance $=\mathrm{N}$ (input) $-\mathrm{N}$ (output)

$=\left(\mathrm{N}_{\text {fertilizer }}+\mathrm{N}_{\text {slurry }}\right)-\left(\mathrm{N}_{\text {crop }}+\mathrm{N}_{\text {volatilized NH3 }}+\mathrm{TN}_{\text {runoff }}\right)$ 
Uusi-Kämppä, J. et al. Nitrogen losses from broadcast or injected slurry

\section{Statistical analyses}

Amounts of grass yield and biomass $\mathrm{N}$ in grass as well as the amounts of $\mathrm{NO}_{3}-\mathrm{N}, \mathrm{NH}_{4}-\mathrm{N}$ and $\mathrm{SMN}$ in the soil $(0-0.6 \mathrm{~m})$ were analysed statistically using a mixed model, where treatment, sampling date and their interactions were used as fixed effects while block, block x treatment and block x sampling date were used as random effects. The soil data were log-transformed before analysis because of skewed distributions.

For statistical analyses of the surface runoff results, log-transformation was used for the $\mathrm{TN}$ and $\mathrm{NH}_{4}-\mathrm{N}$ values. The data from the two study phases were analysed together using a mixed model whereby study, treatment, and their interactions were used as fixed effects, whereas block, block $\times$ treatment, and block $\times$ study were used as random effects. Each block included two or three adjacent plots with different treatments. Soil, plant and runoff analyses were performed using an SAS/MIXED procedure.

The effect of application technique on $\mathrm{NH}_{3}$ concentration in chambers was studied for each measurement period with analysis of variance according to a randomized complete block arrangement (Steel and Torrie 1981) with three replications. The effect was considered significant with $p$ values $<0.05$. The analysis was carried out with the GLM procedure of SAS statistical software version 6.12.

\section{Results and discussion}

\section{Dry Matter and Nitrogen Uptake of Grass}

In Phase I, the mean DM grass yields (8.0-9.3 t $\mathrm{ha}^{-1} \mathrm{yr}^{-1}$ ) and $\mathrm{N}$ uptakes (160-200 $\mathrm{kg} \mathrm{ha}^{-1} \mathrm{yr}^{-1}$ ) were higher in the MF plots than in the slurry treated plots (Table 2). There were no significant differences in the DM yields or $\mathrm{N}$ uptakes between treatments in the first cuts, probably since all the treatments received the same amount of fertilizer $\mathrm{N}$ in spring. In contrast, in the second cuts, the DM yields and $\mathrm{N}$ uptakes were statistically $(p<0.05)$ lower in the slurry treated plots than in the MF plots, although the same amount of mineral $\mathrm{N}$ (ca $80 \mathrm{~kg} \mathrm{ha}^{-1}$ ) was spread in all treatments.

In Phase II (biannual slurry application), the mean DM yields (5.5-7.0 $\left.\mathrm{tha}^{-1} \mathrm{yr}^{-1}\right)$ and $\mathrm{N}$ uptakes (90-125 kg ha-1 $\mathrm{yr}^{-1}$ ) were lower than in Phase I, although the mean applications of mineral $\mathrm{N}$ were 44, 53 and $20 \mathrm{~kg} \mathrm{ha}^{-1} \mathrm{yr}^{-1}$ higher on the SB, IN and MF plots, respectively, than in Phase I. This time, however, three-fourths of the applied mineral $\mathrm{N}$ originated from cattle slurry on the SB and IN plots, whereas in Phase I, half of the mineral $\mathrm{N}$ was from slurry and half from mineral fertilizer. As in Phase I, there were no statistical differences in uptake between the treatments in the first cuts, but in the second cuts, the $\mathrm{N}$ uptake was statistically higher $(p<0.05)$ in the MF and IN plots than in the SB plots in 1998-1999.

\section{Ammonia volatilization}

The $\mathrm{NH}_{3}$ volatilization from SB was considerable, which is indicated both by $\mathrm{NH}_{3}$ volatilization rates in the ambient air and by $\mathrm{NH}_{3}$ concentrations in the chambers (Table 3). Over IN, chamber concentrations of $\mathrm{NH}_{3}$ were low and the volatilization rates in ambient air were close to zero and often slightly negative, which may indicate deposition of $\mathrm{NH}_{3}$ that drifted from SB. Despite this disturbance, it can be concluded that the volatilization of $\mathrm{NH}_{3}$ from injected slurry was small compared with broadcast slurry. To obtain undisturbed results, slurry injection and the subsequent $\mathrm{NH}_{3}$ measurement should have been carried out before broadcasting. However, different timing of the applications would have compromised the comparison of SB and IN by making a difference in the weather conditions at application and during a few days thereafter.

There are also earlier studies showing that injection of slurry into soil effectively prevents $\mathrm{NH}_{3}$ volatilization (e.g. Frost 1994, Dosch and Gutser 1996). Most of the previous work has been done 
Vol. 19(2010): 327-340.

Table 2. Over-ground grass dry matter yields and biomass N. Percentage of biomass $\mathrm{N}$ from the previous mineral $\mathrm{N}$ application is given in parenthesis.

\begin{tabular}{|c|c|c|c|c|c|c|c|c|}
\hline \multirow[t]{2}{*}{ Date of harvest } & \multicolumn{3}{|c|}{ Yield, kg ha-1 } & \multirow[t]{2}{*}{$p$} & \multicolumn{3}{|c|}{ Biomass $\mathrm{N}, \mathrm{kg} \mathrm{ha}^{-1}$} & \multirow[t]{2}{*}{$p$} \\
\hline & SB & IN & MF & & SB & IN & MF & \\
\hline \multicolumn{9}{|c|}{ Annual slurry application (Study phase I) } \\
\hline 13 June 1996 & 4600 & 4600 & 5100 & 0.65 & $150(134)$ & $150(134)$ & $150(134)$ & 0.81 \\
\hline 20 August 1996 & $3800^{\mathrm{a}}$ & $3400^{\mathrm{a}}$ & $4500^{\mathrm{b}}$ & 0.04 & $54^{\mathrm{a}}(69)$ & $49^{\mathrm{a}}(58)$ & $80^{\mathrm{b}}(99)$ & 0.02 \\
\hline Total 1996 & 8400 & 8000 & 9600 & 0.12 & $204(107)$ & $199(101)$ & 230 (119) & 0.16 \\
\hline 23 June 1997 & 5000 & 4700 & 4500 & 0.36 & $85(173)$ & $86(176)$ & $96(196)$ & 0.81 \\
\hline 24 September 1997 & $3300^{\mathrm{a}}$ & $3200^{\mathrm{a}}$ & $4500^{\mathrm{b}}$ & 0.03 & $37^{\mathrm{a}}(47)$ & $37^{\mathrm{a}}(47)$ & $71^{\mathrm{b}}(89)$ & 0.02 \\
\hline Total 1997 & 8300 & 7900 & 9000 & 0.40 & $122(96)$ & $123(97)$ & $167(129)$ & 0.18 \\
\hline Mean 96-97 & 8400 & 8000 & 9300 & & $163(102)$ & $161(99)$ & $199(124)$ & \\
\hline \multicolumn{9}{|c|}{ Biannual slurry application (Study phase II) } \\
\hline 19 June 1998 & 2700 & 3000 & 2500 & 0.11 & $59(123)$ & $63(131)$ & $52(108)$ & 0.11 \\
\hline 4 September 1998 & $2300^{\mathrm{a}}$ & $2700^{\mathrm{b}}$ & $3600^{c}$ & $<0.01$ & $34^{\mathrm{a}}(36)$ & $47^{\mathrm{b}}(48)$ & $57^{\mathrm{b}}(62)$ & 0.01 \\
\hline Total 1998 & $5000^{\mathrm{a}}$ & $5700^{\mathrm{b}}$ & $6100^{\mathrm{b}}$ & 0.03 & $93(65)$ & $110(76)$ & $109(78)$ & 0.08 \\
\hline 24 June 1999 & 4200 & 4000 & 4800 & 0.35 & $81(60)$ & $71(50)$ & $100(100)$ & 0.12 \\
\hline 12 October $1999^{\dagger}$ & 700 & 1100 & 1100 & 0.11 & $14^{\mathrm{a}}(13)$ & $30^{\mathrm{b}}(25)$ & $36^{\mathrm{b}}(36)$ & 0.03 \\
\hline Total 1999 & 4900 & 5100 & 5900 & 0.32 & $95(39)$ & $101(39)$ & $136(68)$ & 0.09 \\
\hline 21 June 2000 & 3100 & 3000 & 3600 & 0.31 & $42(33)$ & $47(35)$ & $56(56)$ & 0.18 \\
\hline 4 October 2000 & 3400 & 4100 & 5300 & 0.20 & $44(47)$ & $60(57)$ & $73(73)$ & 0.13 \\
\hline Total 2000 & 6500 & 7100 & 8900 & 0.22 & $86(39)$ & $107(44)$ & $129(65)$ & 0.13 \\
\hline Mean 98-00 & 5500 & 6000 & 7000 & & $91(48)$ & $106(53)$ & $125(70)$ & \\
\hline
\end{tabular}

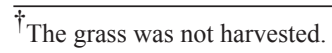

Different letters in the same row indicate a significant difference between treatments $(p<0.05)$.

$\mathrm{SB}=$ surface broadcasting of slurry, $\mathrm{IN}=$ slurry injection, $\mathrm{MF}=$ mineral fertilization

with mass balance or wind tunnel techniques, but the JTI method used in this study has proven to give results comparable with other methods (Misselbrook et al. 2005b). Mattila and Joki-Tokola (2003) used the same JTI equipment as in this study, and measured negligible $\mathrm{NH}_{3}$ volatilization from cattle slurry injected to ley in summer, and a $40 \%$ loss, on average, of $\mathrm{NH}_{4}-\mathrm{N}$ from broadcast slurry. The results reported here indicate that surface application in autumn may cause high losses despite the lower temperature. In cooler weather, the volatilization rate is lower, but total losses may still be considerable, as also observed by Sommer et al. (1991). The effect of temperature on $\mathrm{NH}_{3}$ volatilization is interconnected with many other factors such as solar radiation, air humidity, soil moisture content and drying of manure after application. Temperature as such has not always proven an important factor in determining $\mathrm{NH}_{3}$ volatilization from applied manure (e.g. Braschkat et al. 1997, Sommer and Olesen 2000, Misselbrook et al. 2005a).

On the SB plots, ammonia volatilization was the largest measured single $\mathrm{N}$ flow into the environment $(15 \%$ of $\mathrm{TN}$ application and $24 \%$ of the mineral $\mathrm{N}$ ). The $\mathrm{NH}_{3}$ volatilization was highest on the application day and decreased rapidly during the following two days (Table 3). The decrease is assumed to result from a rainfall and a reduction in the concentration of $\mathrm{NH}_{4}-\mathrm{N}$ in the slurry although not measured after the application. Ammonia volatilization was higher in 2000 than in 
Uusi-Kämppä, J. et al. Nitrogen losses from broadcast or injected slurry

1999, which may have resulted at least partly from higher ambient temperatures (Table 3) and a higher DM content of the slurry: 6.9 and $8.3 \%$ in 1999 and 2000, respectively (Uusi-Kämppä and HeinonenTanski 2008).

\section{Amount of surface runoff}

The mean annual precipitation during the experiment was $626 \mathrm{~mm}(586-673 \mathrm{~mm})$ which is near the longterm (1971-2000) average of $607 \mathrm{~mm}$. On our field, the surface runoff was $10-20 \%$ of the precipitation (Table 4). The mean annual surface runoff (110 $\mathrm{mm}$ ) in the Phase II was comparable to the surface runoff $(110 \mathrm{~mm})$ on a nearby clay soil under timothy and red clover in September 1992-August 1993 (Uusitalo et al. 2007). In Phase I, surface runoff (64 $\mathrm{mm}$ ) was only half of that was measured in Phase II. On a coarse-textured pasture soil, Saarijärvi et al. (2007) measured surface runoff of 66-107 mm which was around $40 \%$ of the total runoff and $15 \%$ of the average precipitation in Eastern Finland. The measured volumes of surface runoff on our field agreed quite well with these findings, indicating that there has been deep percolation (drainflow) as well. However, if the drainage system does not function well or there is no drainage system, the surface runoff can be multifold compared to volumes of drainflow from well-drained grass fields (Turtola and Paajanen 1995, Bilotta et al. 2008).

\section{Nitrogen losses in surface runoff}

Owing to the relatively small amounts of fertilizer and slurry $\mathrm{N}$ in Phase I and lack of heavy rainfall after the slurry applications in summer, losses of TN, $\mathrm{NH}_{4}-\mathrm{N}$ and $\mathrm{NO}_{3}-\mathrm{N}$ in surface runoff were negligible from all treatments over the 18-month monitoring period (Table 4). In fact, the volumes of surface

Table 3. Concentration of $\mathrm{NH}_{3}$ in chambers on surface broadcasting (SB) and injection (IN) plots, $\mathrm{NH}_{3}$ volatilization in ambient air and weather conditions during the measurement periods.

\begin{tabular}{|c|c|c|c|c|c|c|c|c|c|}
\hline \multirow[t]{2}{*}{ Date } & \multirow[t]{2}{*}{ Period } & \multicolumn{2}{|c|}{$\begin{array}{c}\mathrm{NH}_{3} \text { concentration } \\
\mu \mathrm{g} \mathrm{m}^{-3}\end{array}$} & \multirow[t]{2}{*}{$p$} & \multicolumn{2}{|c|}{$\mathrm{NH}_{3}$ volatilization from $\mathrm{SB}$} & \multirow[b]{2}{*}{$\begin{array}{c}\text { Temperature, } \\
{ }^{\circ} \mathrm{C}\end{array}$} & \multirow[b]{2}{*}{$\begin{array}{l}\text { Wind, } \\
\mathrm{m} \mathrm{s}^{-1}\end{array}$} & \multirow[b]{2}{*}{$\begin{array}{c}\text { Precipitation, } \\
\mathrm{mm}\end{array}$} \\
\hline & & SB & IN & & $\begin{array}{l}\text { Volatilization rate } \\
\mathrm{NH}_{3}-\mathrm{N}, \mathrm{g} \mathrm{ha}^{-1} \mathrm{~h}^{-1}\end{array}$ & $\begin{array}{c}\mathrm{N} \text { loss, } \\
\% \text { of } \mathrm{NH}_{4}-\mathrm{N}\end{array}$ & & & \\
\hline \multicolumn{10}{|l|}{1999} \\
\hline 27 Oct & 1 & $7896^{\mathrm{a}}$ & $76^{\mathrm{b}}$ & 0.014 & 1230 & 20 & 6.0 & 2.8 & $1(0.5)$ \\
\hline 27 Oct & 2 & $4216^{\mathrm{a}}$ & $128^{\mathrm{b}}$ & 0.025 & 791 & & 4.0 & 1.6 & 0 \\
\hline $28 \mathrm{Oct}$ & 3 & $1400^{\mathrm{a}}$ & $40^{\mathrm{b}}$ & 0.002 & 220 & & 2.5 & 1.3 & $0(4)$ \\
\hline 29 Oct & 4 & $593^{\mathrm{a}}$ & $29^{\mathrm{b}}$ & 0.000 & 201 & & 10.0 & 2.9 & 0 \\
\hline \multicolumn{10}{|l|}{2000} \\
\hline 23 Oct & 1 & $9657^{\mathrm{a}}$ & $103^{b}$ & 0.032 & 1492 & 33 & 11.0 & 1.4 & 0 \\
\hline 23 Oct & 2 & $7476^{\mathrm{a}}$ & $105^{\mathrm{b}}$ & 0.019 & 920 & & 8.0 & 1.3 & $0(5)$ \\
\hline 24 Oct & 3 & $730^{\mathrm{a}}$ & $55^{\mathrm{b}}$ & 0.016 & 154 & & 9.0 & 3.8 & $<0.5(5.5)$ \\
\hline 25 Oct & 4 & $198^{\mathrm{a}}$ & $32^{\mathrm{b}}$ & 0.013 & 20 & & 9.0 & 3.3 & 0 \\
\hline
\end{tabular}

Superscripts denote statistically significant differences. Volatilization from injected slurry is excluded, because it was close to zero and may have been affected by $\mathrm{NH}_{3}$ drifting from broadcast slurry. Nitrogen loss values include measured emissions from all the four periods and estimated emissions during their intervals. Precipitation between the end of a measurement period and the start of the next period is in parenthesis.

$\mathrm{SB}=$ surface broadcasting of slurry, $\mathrm{IN}=$ slurry injection, $\mathrm{MF}=$ mineral fertilization. 
Vol. 19(2010): 327-340.

Table 4. Precipitation and means of surface runoff and losses of total nitrogen, ammonium nitrogen and nitrate nitrogen to surface runoff water.

\begin{tabular}{|c|c|c|c|c|c|c|c|c|c|c|c|c|c|c|}
\hline \multirow[t]{2}{*}{ Study period } & \multirow{2}{*}{\multicolumn{2}{|c|}{$\begin{array}{l}\text { Precipitation, } \mathrm{n}^{\dagger} \\
\mathrm{mm}\end{array}$}} & \multicolumn{3}{|c|}{$\begin{array}{c}\text { Surface runoff, } \\
\mathrm{mm}\end{array}$} & \multicolumn{3}{|c|}{$\begin{array}{l}\text { Total nitrogen } \\
\mathrm{kg} \mathrm{ha}^{-1}\end{array}$} & \multicolumn{3}{|c|}{$\begin{array}{l}\text { Ammonium } \\
\text { nitrogen }\end{array}$} & \multicolumn{3}{|c|}{ Nitrate nitrogen } \\
\hline & & & SB & IN & MF & SB & IN & $\mathrm{MF}$ & SB & $\mathrm{IN}$ & $\mathrm{MF}$ & SB & $\mathrm{IN}$ & MF \\
\hline \multicolumn{15}{|c|}{ Annual slurry application (Study phase I) } \\
\hline 1 Jan 1996-18 June 1996 & 204 & 11 & 67 & 71 & 63 & 4.6 & 3.9 & 4.6 & 0.7 & 0.8 & 0.9 & 2.1 & 1.2 & 1.5 \\
\hline 19 June 1996-31 Dec 1997 & 1065 & 21 & 56 & 66 & 63 & 2.1 & 2.2 & 1.4 & 0.1 & 0.1 & 0.1 & 0.3 & 0.5 & 0.2 \\
\hline Total & 1269 & 32 & 123 & 137 & 126 & 6.7 & 6.1 & 6.0 & 0.8 & 0.9 & 1.0 & 2.4 & 1.7 & 1.7 \\
\hline \multicolumn{15}{|c|}{ Biannual slurry application (Study phase II) } \\
\hline 1 Jan $1998-16$ Oct 1998 & 507 & 21 & 102 & 104 & 82 & 3.4 & 3.5 & 2.6 & 0.1 & 0.1 & 0.1 & 0.1 & 0.2 & 0.1 \\
\hline 17 Oct $1998-31$ Dec 1998 & 120 & 8 & 36 & 36 & 30 & 9.3 & 1.2 & 0.5 & 3.5 & 0.1 & 0.1 & 0.2 & 0.1 & 0.1 \\
\hline 1 Jan 1999-30 June 1999 & 221 & 16 & 110 & 116 & 99 & 3.6 & 3.0 & 1.6 & 1.2 & 0.3 & 0.2 & 0.3 & 0.3 & 0.2 \\
\hline 1 July 1999-20 Oct 2000 & 845 & 17 & 63 & 63 & 40 & 1.6 & 2.5 & 1.4 & 0.3 & 0.4 & 0.3 & 0.3 & 0.7 & 0.2 \\
\hline 21 Oct $2000-31$ Dec 2000 & 172 & 9 & 29 & 33 & 17 & 1.7 & 2.7 & 0.8 & 0.1 & 0 & 0 & 0.2 & 0.9 & 0.2 \\
\hline Total & 1865 & 71 & 340 & 352 & 268 & 19.6 & 12.9 & 6.9 & 5.2 & 0.9 & 0.7 & 1.1 & 2.2 & 0.8 \\
\hline
\end{tabular}

${ }^{\dagger} \mathrm{n}=$ number of samplings

$\mathrm{SB}=$ surface broadcasting of slurry, $\mathrm{IN}=$ slurry injection, $\mathrm{MF}=$ mineral fertilization

runoff and $\mathrm{N}$ losses were higher before slurry applications during the snow melting in spring 1996.

In Phase II, over the 36-month monitoring period the cumulative losses of $\mathrm{NH}_{4}-\mathrm{N}$ and $\mathrm{TN}$, $5.2 \mathrm{~kg} \mathrm{ha}^{-1}$ and $20 \mathrm{~kg} \mathrm{ha}^{-1}$, respectively, were still relatively small in surface runoff from the plots with slurry broadcasting (Table 4). The TN losses were small, although the slurry TN rates exceeded the currently allowed maximum amount of $170 \mathrm{~kg}$ $\mathrm{ha}^{-1} \mathrm{yr}^{-1}$.

Injection further reduced the originally small surface runoff losses of $\mathrm{NH}_{4}-\mathrm{N}$ and TN by $83 \%$ ( $p$ $<0.001)$ and $34 \%(p<0.01)$, respectively, compared with surface broadcasting, although a little more slurry TN (20-30 kg ha-1 $\left.\mathrm{yr}^{-1}\right)$ was spread on the IN plots. On a fine sandy soil, Turtola and Kemppainen (1998) measured great annual N losses in surface runoff from grass with autumn broadcast slurry, $16-36 \mathrm{~kg} \mathrm{ha}^{-1} \mathrm{yr}^{-1}$ and 7.7-22 $\mathrm{kg} \mathrm{ha}^{-1}$ $\mathrm{yr}^{-1}$ for $\mathrm{TN}$ and $\mathrm{NH}_{4}-\mathrm{N}$, respectively. In their study, however, the amount of TN applied in autumn was one-third higher and the volumes of surface runoff were three times greater than in Phase II of our study. In Norway, Uhlen (1978) reported that surface runoff losses of TN and $\mathrm{NH}_{4}-\mathrm{N}$ were 8 and $4 \mathrm{~kg} \mathrm{ha}^{-1}$, respectively, during the next 14 months after autumn application of $60 \mathrm{t} \mathrm{ha}^{-1}$ semi-liquid cow manure (228 kg TN ha-1) to grass. On boreal pastures, too, the annual losses of $\mathrm{TN}$ in surface runoff were small (below $5 \mathrm{~kg} \mathrm{ha}^{-1}$ ) in the study of Saarijärvi (2008), although the pastures often receive more $\mathrm{N}$ than silage grasses.

However, after slurry application (140-155 kg $\mathrm{TN} \mathrm{ha}^{-1}$ ) to wet soil on October 16, 1998, followed with heavy rainfall $(60 \mathrm{~mm})$ and surface runoff (10 $\mathrm{mm}$ ) during the next two weeks, the mean losses of $\mathrm{TN}$ and $\mathrm{NH}_{4}-\mathrm{N}$ in surface runoff from the SB plots were 9.3 and $3.5 \mathrm{~kg} \mathrm{ha}^{-1}$ over 2.5 months, respectively (Fig. 2), being $47 \%$ of TN and $67 \%$ of $\mathrm{NH}_{4}$ $\mathrm{N}$ losses over the whole 3 -year study phase. During three days after slurry application, incidental TN losses were highest, at $6.8,0.5$ and $0.1 \mathrm{~kg} \mathrm{ha}^{-1}$ from the SB, IN and MF plots, respectively. Soon after slurry application, the mean TN concentration in surface runoff water was $92 \mathrm{mg} \mathrm{l}^{-1}$ for $\mathrm{SB}$, but less for IN (7.6 $\left.\mathrm{mg} \mathrm{l}^{-1}\right)$ and MF (1.2 $\mathrm{mg} \mathrm{l}^{-1}$; Fig. 3). Since concentrations of $\mathrm{NO}_{3}-\mathrm{N}$ and $\mathrm{NH}_{4}-\mathrm{N}$ from $\mathrm{SB}$ plots were $\leq 0.1 \mathrm{mg} \mathrm{l}^{-1}$ and $\leq 51.1 \mathrm{mg} \mathrm{l}^{-1}$, respectively, a large part of TN was in organic form. In June 1998, surface runoff $(4 \mathrm{~mm})$ from the grass stubble was also high with high rainfall $(99 \mathrm{~mm})$ but $\mathrm{N}$ losses 
Uusi-Kämppä, J. et al. Nitrogen losses from broadcast or injected slurry

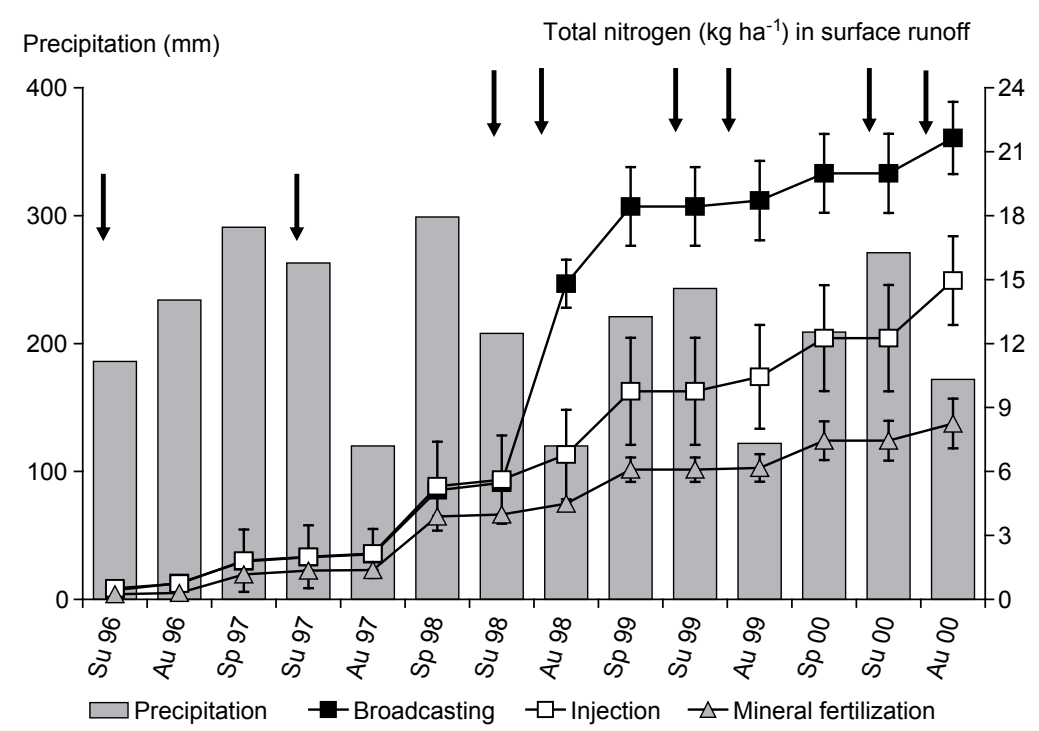

Total nitrogen $\left(\mathrm{mg} \mathrm{l}^{-1}\right)$ in surface runoff

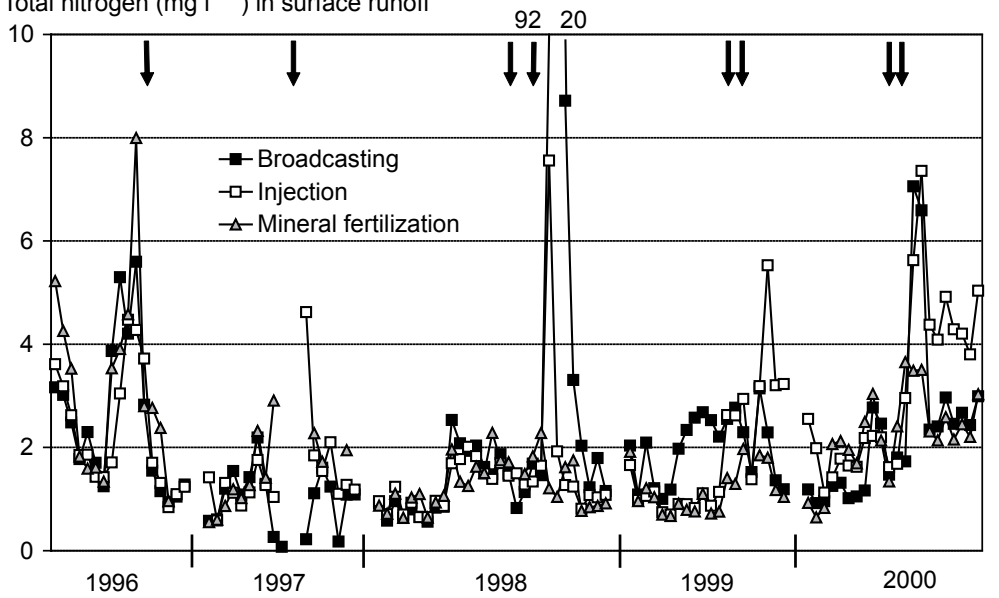

Fig. 2. Cumulative losses of total nitrogen in surface runoff and periodic precipitation from summer 1996 to autumn 2000. Slurry applications are marked by arrows. (Au, autumn; Sp, spring; Su, summer)

Fig. 3. The average concentrations of total nitrogen in surface runoff during 1996-2000. Slurry applications are marked by arrows. The concentration was off scale twice in broadcast plots.

were negligible because slurry had not yet been applied (Fig. 2).

While the $\mathrm{N}$ losses were small on our experimental field with a slope of $0.9-1.7 \%$, losses may be higher on steep slopes with heavy rainfalls soon after slurry application. The surface application of manure is no longer allowed on fields with an average slope of over 10\% (Finlex 2000). Heathwaite et al. (1998) have also shown that the 10-m untreated buffer zone below the source area applied with cattle slurry reduced the TN load by $75 \%$ in surface runoff. Thus in our study, the 10-m buffer zone probably decreased nitrogen losses from all treatments. At present, nitrogen losses from slurry applied fields are mitigated, since the application of $\mathrm{N}$ fertilizers (including slurry $\mathrm{N}$ ) is not allowed 
Vol. 19(2010): 327-340.

on areas closer than 5 metres to a watercourse. And along the width of the next five metres, surface application of $\mathrm{N}$ fertilizers is prohibited if the field slope exceeds two per cent (Finlex 2000). Even wider unmanured areas would be needed on field edges with steep slopes along lakes and rivers to decrease direct $\mathrm{N}$ losses in surface runoff from source fields to water.

The cumulative load of $\mathrm{NO}_{3}-\mathrm{N}$ in surface runoff was small in all treatments $\left(0.8-2.2 \mathrm{~kg} \mathrm{ha}^{-1}\right)$, being highest in the IN plots over the 3-year study phase. The small $\mathrm{NO}_{3}-\mathrm{N}$ losses in surface runoff from grass are consistent with results from studies of Uhlen (1978), Turtola and Kemppainen (1998), Ridley et al. (2001), Smith et al (2001), and Saarijärvi (2008). Ploughing of grass soil in October 2000 increased slightly losses of $\mathrm{NO}_{3}-\mathrm{N}$ and $\mathrm{TN}$ in surface runoff but decreased $\mathrm{NH}_{4}-\mathrm{N}$ losses (Table 4).

\section{Soil mineral nitrogen and nitrogen leaching}

Although in Phase II slurry was spread to the grass ley in autumn, the SMN amounts measured in the following spring were only slightly higher $(0-30 \mathrm{~kg}$ $\left.\mathrm{ha}^{-1}\right)$ or even lower $\left(4-6 \mathrm{~kg} \mathrm{ha}^{-1}\right)$ than the amounts measured in autumn before the slurry applications. This demonstrates that the slurry $\mathrm{N}$ added in the autumn (105-155 kg TN; 60-80 kg NH$-\mathrm{N})$ might have volatilized, become converted to organic form in the soil or leached. In the IN plots, however, the SMN amounts in spring were significantly higher $(p$ $=0.03$ ) than in the SB plots, probably due to lower $\mathrm{NH}_{3}$ volatilization and slightly higher $\mathrm{N}$ input. Also the $\mathrm{NO}_{3}-\mathrm{N}$ amounts were 6-7 $\mathrm{kg} \mathrm{ha}^{-1}$ higher in the IN plots compared to SB plots in May 1999 and in October $1999(p<0.001)$. Cameron et al. (1996) observed that $\mathrm{NO}_{3}-\mathrm{N}$ leaching was consistently higher after subsurface injection of dairy pond sludge compared to surface application. According these results slurry injection may thus increase $\mathrm{N}$ leaching from grass fields.

The summer season 1999 was fairly warm and dry and therefore only one grass yield could be harvested (Table 2). Hooda et al. (1998) and Scholefield et al. (1993) have reported that $\mathrm{NO}_{3}-\mathrm{N}$ leaching is higher after a dry and warm summer than after a wet and cool summer season, since in dry conditions nitrification may be high whereas denitrification and plant uptake of $\mathrm{N}$ can be lower than during cool and wet years. In October 1999 and April 2000, the $\mathrm{NO}_{3}-\mathrm{N}$ amounts in soil were 3-7 $\mathrm{kg} \mathrm{ha}^{-1}$ higher than measured at other times in this study (Fig. 4) and, thus, there was a slightly higher risk for $\mathrm{NO}_{3}-\mathrm{N}$ leaching from the grassland.
Fig. 4. Amounts of soil mineral nitrogen $( \pm$ S.D.) at $0-60 \mathrm{~cm}$ during 1996-2000. The number of weeks passed between previous slurry application and soil sampling is shown inside of the bars.

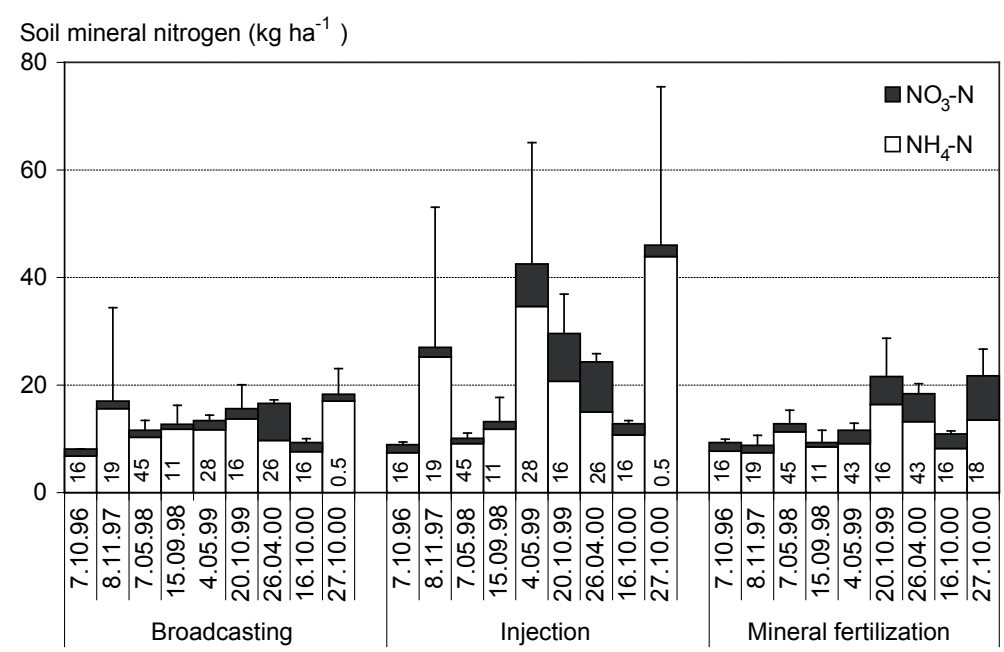


Uusi-Kämppä, J. et al. Nitrogen losses from broadcast or injected slurry

Immediately after ploughing in October 2000, the amount of SMN was greater in the plots where slurry had been previously injected $(p<0.01)$ than in those in which slurry had been broadcast (Fig. 4). In the SB plots, part of the slurry $\mathrm{N}$ was volatilized as $\mathrm{NH}_{3}$ and therefore also the $\mathrm{NH}_{4}-\mathrm{N}$ amounts in soil were smaller than in IN plots $(p<0.01)$.

The experiment continued for 5 years and before that the field had not received manure for years, which increased the capacity of the soil to retain excess slurry N. In this respect, the situation is often different on animal farms, where the same grass fields have been manured for decades. Moreover clay soil has a higher capacity for retaining $\mathrm{NH}_{4}-\mathrm{N}$ than coarse textured soils. Since most Finnish cattle farms are situated on areas with coarse textured soils, the risk for higher $\mathrm{N}$ leaching losses to water is more likely than in our study.

\section{Nitrogen balance and fate of nitrogen}

During the five study years, the cumulative field TN surpluses were 687,971 and $65 \mathrm{~kg} \mathrm{ha}^{-1}$ in the SB, IN and MF plots, respectively (Fig. 5). In Phase $\mathrm{I}, \mathrm{TN}$ balances were negative on the MF plots. In
Phase II, the amount of non-recovered $\mathrm{N}$ was extremely high, up to $58 \%$ (ca $210 \mathrm{~kg} \mathrm{ha}^{-1} \mathrm{yr}^{-1}$ ) and $72 \%$ (ca $280 \mathrm{~kg} \mathrm{ha}^{-1} \mathrm{yr}^{-1}$ ) of the TN input on the SB and IN plots, respectively (Fig. 5). According to Macdonald and Jones (2003), 20-70\% of the N inputs to agricultural systems may be unaccounted for. Although denitrification was not measured it is obvious that large part of organic $\mathrm{N}$ applied in slurry was not mineralized and thus it was not recognized as SMN. In Canada, Bittman et al. (2007) estimated that ca $30 \%$ of applied manure- $\mathrm{N}$ was stored in soil organic matter. A significant amount of $\mathrm{NH}_{4}-\mathrm{N}$ in slurry might also have been microbially immobilized soon after application due to decomposition of fatty acids in slurry (Kirchmann and Lundvall 1993, Sørensen and Amato 2002). According to the results of Huss-Danell and Chaia (2007), over 30 $\mathrm{kg} \mathrm{N} \mathrm{ha-1}$ can be incorporated into grass roots in the northern part of Sweden. Pierzynski and Gehl (2005) showed that some of the $\mathrm{N}$ saved from $\mathrm{NH}_{3}$ emissions may have been lost as $\mathrm{N}_{2} \mathrm{O}$ from slurry injected fields. In a Finnish study, however, only ca $0.7 \%$ of cattle slurry $\mathrm{N}$ incorporated with a disc was lost as $\mathrm{N}_{2} \mathrm{O}$ fluxes (Syväsalo et al. 2006, Perälä et al. 2006). Ammonium can also be fixed into clay minerals or nitrate can be leached into subsurface drains or ground water.
Fig. 5. Input of mineral $\mathrm{N}$ and non-mineral $\mathrm{N}$ and output of $\mathrm{N}$ (plant uptake, $\mathrm{NH}_{3}$ volatilization and $\mathrm{TN}$ in surface runoff) during study Phases I and II.

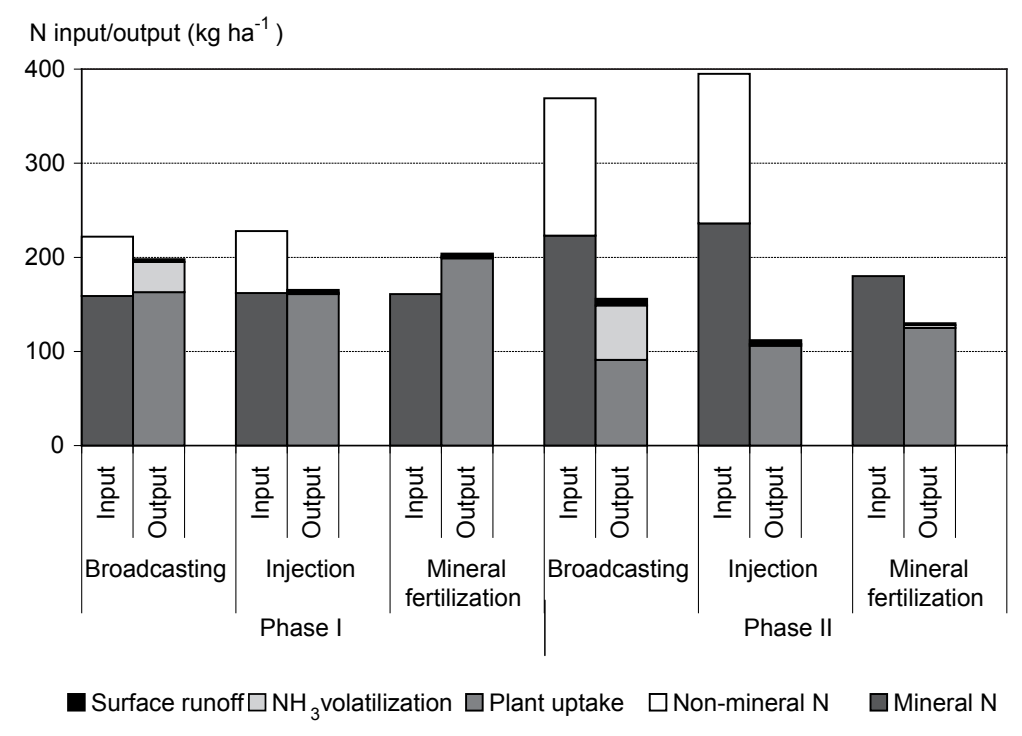


Vol. 19(2010): 327-340.

\section{Conclusions}

Despite cool autumn weather, a considerable portion (20-33\%) of the surface-applied slurry $\mathrm{NH}_{4}-\mathrm{N}$ was lost through ammonia volatilization within a few days after application, but the injection of slurry into the soil effectively prevented this. Nitrogen losses in surface runoff from grass field applied with slurry were small during the five study years, except when heavy rainfall occurred after slurry application in autumn. Although high slurry $\mathrm{N}$ amounts were added to grass, nitrogen leaching risk was surprisingly small from clay soil. If over-dosing of manure would continue longer, however, the situation could be different. When moderate slurry amounts (as in Phase I) are applied in summer and by a technique with low $\mathrm{NH}_{3}$ emissions most of the $\mathrm{N}$ is kept within the nutrient cycle of the farm. These study results can be directly applied to clay soils, whereas on coarse textured soils, the leaching losses may be higher than in this study.

Acknowledgements. We are grateful to Mr. Risto Tanni, Mr. Ari Seppänen, Mr. Aaro Närvänen, Mr. Pekka Kivistö and Mr. Petri Kapuinen, Lic.Sc. (Agr. Eng.) for their technical assistance during the experiment. We thank biometrician Lauri Jauhiainen for his statistical expertise. Critical comments and suggestions by Prof. Eila Turtola, Adjunct Prof. Helvi Heinonen-Tanski and the anonymous referees are gratefully acknowledged. Financial support for this study was provided by the Ministry of Agriculture and Forestry.

\section{References}

Bilotta, G.S., Brazier, R.E., Haygarth, P.M., Macleod, C.J.A., Butler, P., Granger, S., Krueger, T., Freer, J. \& Quinton J. 2008. Rethinking the contribution of drained and undrained grasslands to sediment-related water quality problems. Journal of Environmental Quality 37: 906-914.

Bittman, S., Kowalenko, C.G., Forge, T., Hunt, D.E., Bounaix, F. \& Patni, N. 2007. Agronomic effects of multi-year surface-banding of dairy slurry on grass. Bioresource Technology 98: 3249-3258.

Braschkat, J., Mannheim, T. \& Marschner, H. 1997. Estimation of ammonia losses after application of liquid cattle manure on grassland. Zeitschrift für Pflanzenernährung und Bodenkunde 160: 117-123.

Cameron, K.C., Rate, A.W., Noonan, M.J., Moore, S., Smith, N.P. \& Kerr L.E. 1996. Lysimeter study of the fate of nutrients following subsurface injection and surface application of dairy pond sludge to pasture. Agriculture, Ecosystems \& Environment 58: 187-197.

Dosch, P. \& Gutser, R. 1996. Reducing N losses $\left(\mathrm{NH}_{3}, \mathrm{~N}_{2} \mathrm{O}\right.$, $\mathrm{N}_{2}$ ) and immobilization from slurry through optimized application techniques. Fertilizer Research 43: 165-171.

Drebs, A., Nordlund, A., Karlsson, P., Helminen, J. \& Rissanen P. 2002. Climatological statistics of Finland 19712000. Helsinki: Finnish Meteorological Institute.

Finlex. 1998. Decision of the Council of State on the restriction of discharge of nitrates from agriculture into waters (219/1998). Issued in Helsinki, 19 March 1998. Helsinki: Finlex. Cited 16 April 2009. Available on the Internet: http://www.finlex.fi/fi/laki/alkup/1998/19980219 (in Finnish)

Finlex. 2000. Government Decree on the restriction of discharge of nitrates from agriculture into waters (931/2000). Issued in Helsinki, 9 November 2000. Helsinki: Finlex. Cited 13 March 2009. Available on the Internet: http://www.finlex.fi/fi/laki/kaannokset/2000/ en20000931.pdf

Frost, J.P. 1994. Effect of spreading method, application rate and dilution on ammonia volatilization from cattle slurry. Grass and Forage Science 49: 391-400.

Grönroos, J., Mattila, P., Perälä, P., Nousiainen, J., Regina, K., Saarinen K. \& Mikkola-Pusa, J. 2009. Development of ammonia emission inventory in Finland. Revised model for agriculture. Finnish Environment 8/2009. Helsinki: Finnish Environment Institute. 60 p.

Heathwaite, A.L., Griffiths, P. \& Parkinson, R.J. 1998. Nitrogen and phosphorus in runoff from grassland with buffer strips following application of fertilizers and manures. Soil Use and Management 14: 142-148.

Hooda, P.S., Moynagh, M., Svoboda, I.F. \& Anderson, H.A. 1998. A comparative study of nitrate leaching from intensively managed monoculture grass and grass-clover pastures. The Journal of Agricultural Science 131: 267-275.

Huss-Danell, K. \& Chaia, E. 2007. $\mathrm{N}_{2}$ fixation and nitrogen allocation to above and below ground plant parts in red clower-grasslands. Plant and Soil 299: 215-226.

Kapuinen, P. 1998. A light liquid manure injector for grasslands in polar farming. In: Chastain, J.P. (Ed.) 4th International Dairy Housing Conference, Conference Proceedings. American Society of Agricultural Engineers publication 01-98. St.Joseph, MI, USA: p. 346-354

Kirchmann, H. \& Lundvall, A. 1993. Relationship between $\mathrm{N}$ immobilization and volatile fatty acids in soil after application of pig and cattle slurry. Biology and Fertility of Soils. 15: 161-164.

Macdonald, A.J. \& Jones, D.L. 2003. Missing N: is the solution in dissolved N? In: Hatch, D.J. Controlling Nitrogen Flows and Losses. Wageningen: Wageningen Academic Publishers. p. 600-605.

Malgeryd, J. 1996. Åtgärder för att minska ammoniake- 


\section{Uusi-Kämppä, J. et al. Nitrogen losses from broadcast or injected slurry}

missionerna vid spridning av stallgödsel (Measures to reduce ammonia emissions following application of animal manure). JTI-rapport, Lantbruk \& Industri nr 229. Uppsala: Swedish Institute of Agricultural Engineering. (In Swedish with English summary). $126 \mathrm{p}$.

Mattila, P.K. \& Joki-Tokola. E. 2003. Effect of treatment and application technique of cattle slurry on its utilization by ley: I. Slurry properties and ammonia volatilization. Nutrient Cycling in Agroecosystems 65: 221-230.

Ministry of Agriculture and Forestry. 1998. Perustuki maatiloille. 1998 Maatalouden ympäristötuki. Helsinki: Ministry of Agriculture and Forestry. 32 p. (In Finnish).

Misselbrook, T.H., Nicholson, F.A. \& Chambers, B.J. 2005a. Predicting ammonia losses following the application of livestock manure to land. Bioresource Technology 96: 159-168.

Misselbrook, T.H., Nicholson, F.A., Chambers, B.J. \& Johnson, R.A. 2005b. Measuring ammonia emissions from land applied manure: an intercomparison of commonly used samplers and techniques. Environmental Pollution 135: 389-397.

Perälä, P., Kapuinen, P., Esala, M., Tyynelä, S. \& Regina, K. 2006. Influence of slurry and mineral fertiliser application techniques on $\mathrm{N}_{2} \mathrm{O}$ and $\mathrm{CH}_{4}$ fluxes from a barley field in southern Finland. Agriculture, Ecosystems \& Environment 117: 71-78.

Pierzynski, G.M. \& Gehl, K.A. 2005. Plant nutrient issues for sustainable land application. Journal of Environmental Quality 34: 18-28.

Puustinen, M. 1994. Effect of soil tillage on soil erosion and nutrient transport in plough layer runoff. Publications of the Water and Environment Research Institute 17: 71-90. Helsinki, National Board of Waters and the Environment, Finland.

Ridley, A.M., White, R.E., Helyar, K.R., Morrison, G.R., Heng, L.K. \& Fisher, R. 2001. Nitrate leaching loss under annual and perennial pastures with and without lime on a duplex (texture contrast) soil in humid southeastern Australia. European Journal of Soil Science 52: 237-252.

Saarijärvi, K. 2008. Nitrogen cycling on intensively managed boreal dairy pastures. Doctoral Dissertation. Agrifood Research Reports 134. Jokioinen: MTT Agrifood Research Finland. 71 p. Cited 15 April 2010. Available on the Internet: http://www.mtt.fi/met/pdf/met134.pdf

Saarijärvi, K., Virkajärvi, P. \& Heinonen-Tanski, H. 2007. Nitrogen leaching and herbage production on intensively managed grass-clover pastures on sandy soil in Finland. European Journal of Soil Science 58: 1382-1392.

Scholefield, D., Tyson, K.C., Garwood, E.A., Armstrong, A.C., Hawkins, J. \& Stone, A.C. 1993. Nitrate leaching from grazed grassland lysimeters: effects of fertilizer input, field drainage, age of sward and patterns of weather. Journal of Soil Science 44: 601-613.

Sippola, J. \& Yläranta, T. 1985. Mineral nitrogen reserves in soil and nitrogen fertilization of barley. Annales Agriculturae Fenniae 24: 117-124.
Smith, K.A., Jackson, D.R. \& Pepper, T.J. 2001. Nutrient losses by surface run-off following the application of organic manures to arable land. 1. Nitrogen. Environmental Pollution 112: 41-51.

Soil Survey Staff, 1996. Keys to soil taxonomy. 7th ed. Washington, DC: USDA, Natural Resources Conservation Service.

Sommer, S.G. \& Olesen, J.E. 2000. Modelling ammonia volatilization from animal slurry applied with trail hoses to cereals. Atmospheric Environment 34: 2361-2372.

Sommer, S.G., Olesen, J.E. \& Christensen, B.T. 1991. Effects of temperature, wind speed and air humidity on ammonia volatilization from surface applied cattle slurry. The Journal of Agricultural Science 117: 91-100.

Sørensen, P. \& Amato, M. 2002. Remineralisation and residual effects of $\mathrm{N}$ after application of pig slurry to soil. European Journal of Agronomy 16: 81-95.

Steel, R.G.D. \& Torrie, J.H. 1981. Principles and procedures of statistics, 2nd ed. McGraw-Hill, Singapore.

Svensson, L., 1994. A new dynamic chamber technique for measuring ammonia emissions from land-spread manure and fertilizers. Acta Agriculturae Scandinavica, Section B, Soil Plant Science 44: 35-46.

Syväsalo, E., Regina, K., Turtola, E., Lemola, R. \& Esala M. 2006. Fluxes of nitrous oxide and methane, and nitrogen leaching from organically and conventionally cultivated sandy soil in western Finland. Agriculture, Ecosystems \& Environment 113: 342-348.

Turtola, E. 1989. Effect of storage and sulphuric acid addition on analytical results of nitrogen and phosphorus in water samples containing eroded material. Aqua Fennica 19(2): 109-112.

Turtola, E. \& Kemppainen, E. 1998. Nitrogen and phosphorus losses in surface runoff and drainage water after application of slurry and mineral fertilizer to perennial grass ley. Agricultural and Food Science in Finland 7: 569-581.

Turtola, E. \& Paajanen, A. 1995. Influence of improved subsurface drainage on phosphorus losses and nitrogen leaching from a heavy clay soil. Agricultural Water Management 28: 295-310.

Uhlen, G. 1978. Nutrient leaching and surface runoff in field lysimeters on a cultivated soil. II. Effects of farm yard manure spread on a frozen ground and mixed in the soil on a water pollution. Scientific Reports of the Agricultural University of Norway. 57(28): 1-23.

Uusi-Kämppä, J. \& Heinonen-Tanski, H. 2008. Evaluating slurry broadcasting and injection to ley for phosphorus losses and fecal microorganisms in surface runoff. Journal of Environmental Quality 37: 2339-2350.

Uusitalo, R., Turtola, E. \& Lemola, R. 2007. Phosphorus losses from a subdrained clayey soil as affected by cultivation practices. Agricultural and Food Science 16: 352-365. 